\title{
Editorial
}

\section{Europe's Digital Single Market Advances}

The European Union has launched a new eGovernment Action Plan 2011-2015 that signals a new generation of open, flexible and collaborative eGovernment services for citizens and businesses. The Commission in its announcement of this ambitious detailed initiative indicated "this Action Plan contributes to a knowledge-based, sustainable and inclusive economy for the European Union, as set for the in the $\mathrm{Eu}-$ ropean 2020 Strategy and supports the Digital Agenda for Europe."

Although across Europe the level of e-Government readiness has increased, the Commission Vice President responsible for the Digital Agenda, Neelie Kroes points out that "online take-up is often still low and sophistication remains limited" in the 27 national economies comprising the Union. The level of cross- border electronic services, both business and government, remain hampered by lack of complementary laws and regulations as well as technical standards for effective interfacing. The Special Report in this issue presents The Digital Agenda in detail describing both the extensive problems as well as ways and means for their solution.

Of particular interest to many Journal readers will be the detailed e-Government reports providing basic data, legal framework, infrastructure as well as government services to citizens and businesses details for each of the 27 Member States and 7 candidate countries that are available on the e-Practice website (www.epractice.eu).

Russell Pipe, Editor in Chief 